3. "[T]he use of fairies as 'white lie' for property theft was practiced primarily although not wholly by males. The female domain, in the bearing and raising infants and small children, provides a somewhat more complex use of fairy allusions" (41).

4. J. C. Scott, Weapons of the Weak

(New Haven: Yale University Press, 1985).

5. Stephen Greenblatt, Shakespearean Negotiations (Los Angeles: University of California Press, 1988), pp. 78-79.

6. G. K. Paster, Humouring the Body (Chicago: The University of Chicago Press, 2004); M. C. Schoenfeldt, Bodies and Selves in Early Modern England (Cambridge: Cambridge University Press, 1999).

\section{New Books by Hazlitt, New Place for Hazlitt}

\author{
Duncan Wu (ed.), New Writings of \\ William Hazlitt, 2 volumes (Oxford: \\ Oxford University Press, 2007)
}

These two lavishly edited volumes of new writings by William Hazlitt might come as a surprise to those who still see Hazlitt as an interesting minor voice from the Romantic period. With these books on the table, one looks back on the changing reputation of the essayist as an amazing story of success (with the unavoidable dissenting opinions). After the steady, but almost unexamined reception of his work through the Victorian period, and the relative neglect of it in the first half of the twentieth century, Hazlitt began to come into his own with the rise of scholarly interest in the history of criticism in the midcentury. Walter Jackson Bate, for example, cast a very influential vote in placing Hazlitt among the most significant critics of all times in his Criticism: The Major Texts (1952).

In lending authority to Hazlitt's criticism, the significance of this anthology, in which 7 pages are allotted to Plato, 19 to Aristotle, while to Hazlitt an astonishing 38, can hardly be overstated. In his introductory essay to the Hazlitt section, Bate stressed the importance of the sympathetic imagination in Hazlitt's moral psychology and his criticism as well. ${ }^{1}$ He elaborated the history of that concept in a well-known paper of $1945,{ }^{2}$ and went on to present it as a central problem in his great study of Keats, in relation to the poet's ideas connected to "negative capability."3 With this he managed to place Hazlitt in a critical tradition of unquestionable importance, but left an important question open: examining Hazlitt's work seems justified only in so far as it contributes to our understanding of the theory and practice of Keats.

David Bromwich in his 1983 Hazlitt: The Mind of a Critic still felt it necessary to justify producing a very thick book on the essayist in the following terms: "In making large claims for a critic better known to his contemporaries than to posterity, one faces the 
question whether this is a task of antiquarian history or part of the history of the present. About any such writer one wants to know who read him then, that we should read him now. With Hazlitt the answer can be simple and satisfying. He was read by a genius of the next generation, who pronounced Hazlitt's 'depth of taste' one of the three things to be prized in that age - alongside Haydon's paintings and The Excursion - and who sought his company in person, for conversation, for practical suggestions, and for theoretical counsel."4

Hazlitt was not omitted from the large classics in the history of criticism that came out in the years following the publication of Bate's anthology either. In M.H. Abrams's The Mirror and the Lamp (1953) Hazlitt's name features in the title of as many as two chapters, and props up in a number of other places as well; nevertheless, in the most extended discussion that he receives he is described as the critic who mediated between the Longinian critical tradition and John Keats. The criterion of "intensity" Keats is said to have derived from Hazlitt, who, once again is appreciated for his part in the maturing of the greatest mind of the next generation, but is certainly not seen as an author whose output is interesting in other respects as well.

It was in 1955 that the second volume of René Wellek's A History of Modern Criticism 1750-1950, the one covering
The Romantic Age was published. Wellek already pays some attention to the specific qualities of Hazlitt's work. He carefully distinguishes Hazlitt's outlook from those of Coleridge and August Wilhelm Schlegel, examines the parallels with Charles Lamb, looks for possible sources, weights the advantages and disadvantages of Hazlitt's "impressionism," compares some of his most memorable critical statements with twentieth-century views, 5 and ultimately turns the common procedure upside down, that is, he relegates Keats to an "appendix to Hazlitt."6

George Watson's The Literary Critics (1962), if not on a level with the classics that precede it, is a good example of the discontents of Hazlitt's raising fame. The less then four pages Hazlitt receives in this book contain almost nothing but an outpour of intense dislike, usually left unsubstantiated. Hazlitt is not capable of serious analysis, he is "simple-minded," he is "like a schoolboy in hurry with his homework anxious to impress his master with a taste for rhetoric." There is "hopeless confusion" in his writings, which is only what you would expect from a "critic who flaunts his own personality at the expense of his subject," and who is "not saying anything, he is simply making a noise to suggest that he is, or has been, excited about something." The bombastic conclusion sounds like this: "he is the father of our Sunday journalism." 7 
Probably one of the reasons why Watson may have felt it unnecessary to further corroborate his sweeping denunciation of Hazlitt, is that the authority of T. S. Eliot was still strong enough to uphold any statement in agreement with his views. It was John Kinnaird who pointed out in 1978 that Eliot's passing statement in his essay "John Dryden," that Hazlitt "had perhaps the most uninteresting mind of all our distinguished critics," was "almost literally the sentence of death for Hazlitt's reputation in this century (or until very recent years) as a critic of poetry." 8

It was, then, in the 1970s that booklength studies began to appear on Hazlitt. Roy Park in 1971 examined his place in the romantic period with more attention than anyone before, but has been criticised for ultimately falling back upon the old notion of Hazlitt as a precursor to Keats's "negative capability."9 Kinnaird's above-quoted study was the first to seriously question the view that squares Hazlitt with Keats. Two relevant books by John L. Mahoney, and Bromwich's study all emphasise the Keats-connection, but they, especially the last one, which still remains the single most detailed holistic interpretation of Hazlitt's oeuvre, heavily contributed to the readiness to accept Hazlitt as one of the major voices of the romantic period. Finally, it was left to Uttara Natarajan, in her still unchallenged Hazlitt and the Reach of
Sense (1998), to argue for taking Hazlitt seriously as a philosopher, and to radically dissever almost all connection with Keats, at least as it was traditionally seen. In her view, most literature on Hazlitt is trapped in the problem of egotism versus disinterestedness, which, however, "is easily removed when we separate Hazlitt from Keats to decipher his theory of genius as a theory of power, that is, a theory not of self-annihilation, but of selfaffirmation."1o

Hazlitt, then, does not lack supporters these days. Here is Tom Paulin, probably the fiercest of them all: "[w]e have for too long allowed Wordsworth and Coleridge to overshadow or occlude Hazlitt's genius, and it is for a new generation of readers and scholars to restore him to his rightful place as philosopher, master critic, political journalist and unequalled prose stylist." ${ }^{11}$ In 2003, labour leader Michael Foot unveiled the restored Hazlittmonument in Soho, on which an unknown hand (maybe his first wife, Sarah Stoddart, which would be a case of almost unexplainable generosity) describes Hazlitt as, amongst other things "The first (unanswered) Metaphysician of the age.... A lover of the People, poor or oppressed: A hater of the Pride and Power of the Few... A man of true moral courage."12 Today we have a Hazlitt Day-School, titled England's Missing Critic? William Hazlitt 
(established in 2001), we have a Hazlitt Society that hosted the third annual Hazlitt lecture in September 2007, and which is planning to launch an annual Hazlitt Review. ${ }^{13}$ But the towering achievement of all these attempts is that of Duncan Wu. In 1998 he brought out an acclaimed 9-volume Selected Writings of William Hazlitt; 14 a muchneeded updating of P.P. Howe's edition of the Complete Works (1930-34). He is currently working on a biography of Hazlitt, which, judging by his recent publications, will be a very important source, clarifying, at long last such essential issues as Hazlitt's intellectual background and reading. And now he has published the New Writings, which includes a number of items earlier attributed to Hazlitt by Stanley Jones, Jules Douady, and others, but also many never before seen as his.

Two huge beautiful hardbacks, luxurious in execution, overawing in scholarly apparatus, the very sight and touch of New Writings by William Hazlitt toss aside all questions as to Hazlitt's importance. Obviously it is a classic of the English language that we are dealing with, not a single word of whose is to be allowed to get lost. Since most of the items here attributed to Hazlitt appeared anonymously, and no manuscript survives, attribution is argued either by circumstance or by "diction, style, and content. Of the first, there is less to draw on than with other Roman- tic writers, so that the latter assumes considerable importance" (1.lix). Duncan $\mathrm{Wu}$ is disarmingly honest when it comes to the more slippery areas of the editor's job. "Only in a certain proportion of cases can one be sure of Hazlitt's authorship. Usually it is a strong probability, somewhere between 'highly likely' and 'near certain,' the evidence not permitting the case to be more strongly put" (1.lxiii-lxiv). And indeed, it is not often that one sees so many conditionals in a scholarly commentary to a critical edition: "it is likely that, had he seen this news item, he would have responded as the writer does here" (2.271); "I imagine that Stanley Jones (who first suggested this attribution) would have argued etc. (2.136)."

But if identifying texts by style is unavoidably fraught with problems, $\mathrm{Wu}$ is as convincing as anyone can be. He has the almost uncanny ability to recognise even the most minute Hazlittian (a word he likes to use very much) turns of phrase. Has he committed the whole oeuvre to memory, one is tempted to wonder. He is also brilliant at describing Hazlitt's style. "[T]he prose is taut, eloquent, and witty ... the metaphor precise and evocative" (2.369). Hazlitt is set aside from most journalists by his ability to think "about contemporary events in Shakespearean terms," and "as a trained artist" to "see the world in artistic terms," he is "prone to aphorism," "happy to use the rhetorical 
question," even "in series," expert at repeating words, phrases and rhythms for effect," and has a keen "sense of the ridiculous" (1.lix-lxii). There is the problem, of course, that Hazlitt's style, like any other style, "can be imitated," but, Wu reassures us, "Hazlittian thought is beyond imitation" (1.lxii).

Uttara Natarajan has described the "canonising purpose" of Wu's editorial practice. 15 Nothing shows this better than his determination to collect any text, where there is some likelihood that it may have come from Hazlitt. A complete essay is included by Charles Lamb, for instance, because it contains, so Lamb tells his readers, one paragraph by Hazlitt. "None of this points unswervingly to Hazlitt, but the evidence suggests him rather than his colleagues" (2.280), "The nature of the evidence precludes a conclusive case, but it remains a strong one" (2.354), "the paucity of evidence leaves one with little choice but to speculate" (2.431). At times one feels that quality is the strongest indicator of Hazlitt's hand. The primary meaning of "Hazlittian" for Wu seems to be "strikingly good."

The second volume has a section entitled "Early Versions of Selected Essays," which Wu introduces by complaining that "[o]ur understanding of Hazlitt's texts and his development is at a primitive stage compared with that of any major writer of the period. The successive manuscript drafts that lie behind The Prelude have long been in print, not to mention a number of different versions of the poem itself" (2.429). Side by side with The Prelude: there is surely no higher place than that for any Romantic text!

Virginia Woolf believed that Hazlitt "will live in a volume of essays in which is distilled all those powers that are dissipated and distracted elsewhere, where the parts of his complex and tortured spirit come together in a truce of amity and concord." $16 \mathrm{Wu}$ emphasises that here we see not Hazlitt the essayist (and even less Hazlitt the philosopher) but Hazlitt the busy journalist. Taken together with the commentary, which as Charles Lamb said about Coleridge's annotations "in matter oftentimes, and almost in quantity not unfrequently, vi[es] with the originals" 17 presents splendid pictures of the life of the newspaperman in the "mighty metropolis, where," in Hazlitt's powerful description, "myriads of human hearts are throbbing - where all that is busy in commerce, all that is elegant in manners, all that is mighty in power, all that is dazzling in splendour, all that is brilliant in genius, all that is benevolent in feeling, is congregated together" ("London Solitude," ii. 355). "He could have begun his evening," Wu recounts in one of the places, where the commentary comes alive with excitement, "at Covent Garden, watching Reynolds's play, before making the 
journey to Drury Lane (a walk of five minutes, if that) for the afterpiece there. As soon as the curtain dropped, he hot-footed it to the Times printinghouse in Blackfriars, where he dictated his review to the setter" (1.265).

Probably most readers will be interested in the reviews on the major contemporary poets. The one on Wordsworth's 1827 Poetical Works is a strange companion-piece to the portrait of the poet-revolutionary in The Spirit of the Age: the older Wordsworth appears completely lacking in power; he is described "as the passive subject of monarchy" (2.38), somewhat similarly to Coleridge, whom Hazlitt forever criticises for his weakness of will, and is in one of the newly collected essays classed among "the more placid genius[es]" (1.133).18 If power lays hold on us principally through aesthetic means (through the imagination), as Hazlitt argues for instance in "The Spirit of Monarchy" (1823), then it takes extreme force of the understanding or a figure that grasps the imagination instead of "legitimate" (a veritable swearword with Hazlitt) power. Hence the efforts of Hazlitt to transform Napoleon into such a powerful image.

The reviews of Coleridge are mostly savage, and the frightening figure that Wu provides, demonstrating Hazlitt's animus, is that "[d]uring the course of nine months he attacked The Stateman's Manual no less than four times"
(1.205). There are interesting statements about Shelley, however, which show that he could be far more sympathetic towards the poet, with whom he was acquainted, than it appears from the incomprehensibly harsh review of Shelley's posthumously collected works (the major statement that has been available).

The texts related to Napoleon are fascinating, and shed new light on a much debated field. Paul Johnson in 2004 wrote with fury about Hazlitt's allegedly blind cult of Napoleon. "Of course, force and its shameless use in supposedly progressive causes, has always appealed to left-wing intellectuals. Hazlitt not only backed Napoleon at all stages, but wrote an interminable and unreadable life of him. He is the exact equivalent, c 1810, of the Shaws and Webbs who, c 1930, glorified Stalin."19 In light of the material now made available by Duncan Wu this position looks utterly flawed, and seems to give further evidence to Simon Bainbridge's view, who concluded that "Hazlitt's writing on Napoleon Bonaparte, then, was no simple indulgence of his own idolatry, but a calculated campaign of imaginative terrorism," where the keyword is "calculated."2o In fact, Hazlitt, in one of the newly collected pieces confesses that "Bonaparte was not the personification of our beau ideal of a hero. He partook too much of the egoism of the old model" (1.480). He 
speaks about the emperor's "fearful repose upon the simple elements of force" (1.479). Additionally, "[t]here is something interesting to the feelings, although repulsive to the judgment in the enthusiasm of M. Savary [for Napoleon]. We are no admirers of the military profession" (2.145). This, of course, is not to deny that, as Wu says, Hazlitt's perspective was "distinctively proNapoleonic" (2.103). But it is a reminder that we ought to be cautious when charging Hazlitt with unthinking dictator-worship.

Finally, may I confess that I still find those essays the most intriguing where we get a glimpse of Hazlitt the familiar essayist. Anyone who has no time to read through the two volumes should directly go to the late piece "On Table Companions and the Art of Dining." This delightful essay amounts to a retrospective ars poetica composed by the writer almost on his death-bed: "Companionship, which is the essence of a pleasant party, demands equality among diners" (2.402).

\section{Bálint Gárdos}

\section{Notes}

1. "[T]here is one point of view which permeates and colors many of his other principles and gives a certain unity to his criticism: that is, his conception of the sympathetic character of the imagination, and his belief in the absolute dependence of great art upon it" (Walter Jackson Bate, Criticism: The Major Texts, Enlarged Edition [New York: Harcourt Brace, 1970], p. 283).
2. Walter Jackson Bate, "The Sympathetic Imagination in Eighteenth-Century English Criticism," ELH 12 (1945) 144-164. 3. Walter Jackson Bate, John Keats (Cambridge, Mass.: Harvard University Press, 1963).

4. David Bromwich, Hazlitt: The Mind of a Critic (New Haven and London: Yale University Press, 1999), p. 362. For lists and evaluation of the relevant literature see: Uttara Natarajan, Hazlitt and the Reach of Sense: Criticism, Morals, and the Metaphysics of Power (Oxford: Clarendon Press, 1998), 107-119 (especially p. 109) and Roy Park, Hazlitt and the Spirit of the Age: Abstraction and Critical Theory (Oxford: Clarendon Press, 1971), 26-42 (especially pp. 34-35).

5 . This was exactly the problem: the history of criticism was not yet an autonomous field of study. See Péter Dávidházi, Hunyt mesterünk: Arany János kritikusi öröksége, 2nd ed. (Budapest: Argumentum, 1994), 15-71, especially pp. 67-71.

6. René Wellek, The History of Modern Criticism 1750-1950: The Romantic Age (Cambridge: Cambridge University Press, 1981), p. 212.

7. George Watson, The Literary Critics: A Study of English Descriptive Criticism (London: Hogart Press, 1986) pp. 124-5.

8. John Kinnaird, William Hazlitt: Critic of Power (New York: Columbia University Press, 1978), p. 211.

9. Natarajan, p. 108.

10. Natarajan, pp. 8-9.

11. Tom Paulin, "One Impulse: Hazlitt, Wordsworth and The Principles of Human Action," in Metaphysical Hazlitt: Bicentenary essays, ed. Uttara Natarajan, Tom Paulin and Duncan Wu (London and New 
York: Routledge, 2005) 98-111, p 111. See also Paulin, The Day-Star of Liberty: William Hazlitt's Radical Style (London: Faber and Faber, 1998).

12. Tom Paulin, "Spirit of the Age," The Guardian 5 April 2003 <http://books .guardian.co.uk/review/story/o,12084,929 528,oo.html>.

13. See http://www.williamhazlitt.org.

14. See, for instance, Robert Morrison, "Well-Feathered Thoughts," Essays in Criticism 52.3 (2002) 258-262.

15. Uttara Natarajan, [untitled review], The Review of English Studies, 240/59 (2008) 470-472.

16. Virginia Woolf, "William Hazlitt," in The Second Common Reader (New York: Harcourt, Brace \& World, 1960), 156-166, p. 166.

17. Charles Lamb, "The Two Races of Men," in The Works of Charles and Mary Lamb, ed. E. V. Lucas (London: Methuen, 1903), 22-27, pp. 26-7.

18. Seamus Perry notes this in his review of the volumes: "A man of singular opinions," TLS, 18 April 2008, p. 12.

19. Paul Johnson, "A Role Model for All Dictators," The Daily Telegraph 17 October 2004 <http://www.telegraph.co.uk/arts/ main.jhtml?xml=/arts/2004/10/24/bohaz2 4.xml\&sSheet=/arts/2004/10/24/bomain .html>.

20. Simon Brainbridge, Napoleon and English Romanticism (Cambridge: Cambridge University Press, 1995), p. 207. More recently, Paul Stock has written about Hazlitt's conscious use of Napoleon as an "ideological symbol" (Stock, "Imposing on Napoleon: The Romantic Appropriation of Bonaparte," Journal of European Studies 36.4 [2006] 363-388).

\section{Representability and Pathological Discipline}

Philippe-Alain Michaud, Aby Warburg and the Image in Motion, translated by Sophie Hawkes, foreword by Georges Didi-Huberman (New York: Zone Books, 2004)

Scholars who have tried to give an overall description of Aby Warburg's structure of theory have always faced enormous difficulties. He himself admitted the presence of a private overtone in all his works, something he called an "autobiographical reflex." 1 It is this private tone in Warburg's style; increasingly deviating from the accepted conventions of academic prose, with hints to meanings that were not explicitly stated, that has proved to be the most difficult challenge for scholars. These private dimensions may be further expanded by taking into consideration the huge amount of notes and drafts he never intended to see in print. ${ }^{2}$

The style of the few studies he edited is very dense and strict and the notes and drafts sometimes explore an embarrassingly private and relaxed sphere of a scholar's mind. The fact that the number of studies he published throughout his life is very small, there are many themes he only planned to write about, give his oeuvre an unfinished character, at the same 